\title{
REVALIDATION OF LATRODECTUS THORACICUS NICOLET, 1849 (ARANEAE: THERIDIIDAE): BIOLOGICAL AND PHYLOGENETIC ANTECEDENTS
}

\author{
REVALIDACION DE LATRODECTUS THORACICUS NICOLET, \\ 1849 (ARANEAE: THERIDIIDAE): ANTECEDENTES BIOLOGICOS Y \\ FILOGENETICOS
}

\author{
Milenko A. Aguilera, Guillermo D’Elía \& María E. Casanueva \\ Departamento de Zoología. Facultad de Ciencias Naturales y Oceanográficas. Universidad de Concepción, Casilla \\ 160-C, Concepción, Chile. \\ E-mail: milenko.aguilera@udec.cl
}

\begin{abstract}
The number and identity of the species of black widow spiders of the genus Latrodectus that inhabit Chile remain unclear. Here we present results of taxonomic work based on morphologic and molecular characters of a large series of specimens collected throughout Chile, which aimed to assess Chilean Latrodectus diversity. Results show that all studied populations belong to a single species, for which the correct name is Latrodectus thoracicus Nicolet 1849. Therefore, we remove this taxon from the synonymy of $L$. mactans (Fabricius, 1775). In addition, we suggest that $L$. mirabilis (Holmberg, 1876) may be junior synonym of L. thoracicus. We recognize two species of black widows for continental Chile, L. thoracicus and L. variegatus Nicolet, 1849. We provided an emended diagnosis and comprehensive description of $L$. thoracicus as well as new locality records and novel data on its natural history. Given our results, we recommend the continued collecting specimens and more collection based taxonomic work as the only way of gathering a correct appreciation of Latrodectus diversity in southern South America.
\end{abstract}

KeYwords: Chile, species limits, taxonomy, Black widows.

\section{RESUMEN}

El número e identidad de las especies de viudas negras del género Latrodectus que habitan Chile no es claro. En este trabajo presentamos resultados de un estudio taxonómico basado en caracteres morfológicos y moleculares de una serie grande de especímenes colectados a lo largo de Chile, cuyo objetivo fue evaluar la diversidad de Latrodectus en Chile. Los resultados indican que las poblaciones estudiadas pertenecen a una misma especie, para la cual el nombre correcto es Latrodectus thoracicus Nicolet 1849. Por lo tanto removimos dicho taxón de la sinonimia de L. mactans (Fabricius, 1775). Además, sugerimos que L. mirabilis (Holmberg, 1876) puede constituir un sinónimo junior de L. thoracicus. Reconocemos dos especies de viudas negras para Chile continental, thoracicus y L. variegatus Nicolet, 1849. Proveemos una diagnosis enmendada y una descripción detallada de L. thoracicus así como nuevas localidades de registro y datos sobre su historia natural. A la luz de nuestros resultados, afirmamos que es imperioso continuar realizando colecta de especímenes y trabajo taxonómico basado en colecciones como la única forma de obtener una correcta apreciación de la diversidad de Latrodectus en el sur de América del Sur.

Palabras Clave: Chile, límites de especies, taxonomía, viudas negras. 


\section{INTRODUCTION}

Latrodectus Walckenaer, 1805 is a diverse and cosmopolitan genus of theridiid spiders with 30 recognized species (Platnick 2009). It is considered a taxonomically complex genus as the status of several forms have not been properly evaluated and specific boundaries are not well defined or understood (Garb et al. 2004; Levi 1959, 1967a); therefore, in multiple cases, populations have been uncritically referred to as different taxa.

The members of this genus are of medical importance due to the potency of their venom, which contains a neurotoxin that produces a massive liberation of neurotransmitters. Among the proteins that cause the latrodectism one of the most important is the $\alpha$-latrotoxin (Ori \& Ikeda 1998; Grishin 1999; Orlova et al. 2000). Biochemical studies have been done to identify the proteins present in some Chilean Latrodectus specimens. The results have been coincident with those based on North American and European species (Romero et al. 1996, 2000). Medical and related literature has associated the Chilean cases of latrodectism with Latrodectus mactans (Fabricius, 1775) (Artaza et al. 1982, Artaza et al. 1984; Schenone \& Correa 1985; Romero et al. 2003; Parodi et al. 2008) or with L. curacaviensis (Muller, 1776) (Faúndez 2009). However, the number and identity of the species of Latrodectus inhabiting Chile, is for the moment not clear (Canals et al. 2004); therefore it is not possible to determine which species of Latrodectus cause latrodectism in Chile.

The genus Latrodectus has a wide distribution in Chile, ranging from the deserts of the north $\left(20^{\circ} \mathrm{S}\right)$ to the Patagonian steppes near the Magellan Strait (approximately $50^{\circ} \mathrm{S}$ ). The number and identity of the species of Latrodectus currently inhabiting Chile are not well known. This is due to the complex taxonomic history of the diverse forms of Latrodectus, and to the lack of studies that have included Chilean specimens. The first records of Latrodectus in Chile were provided by Nicolet (1849), who described Latrodectus variegatus Nicolet 1849 and Latrodectus thoracicus Nicolet, 1849 with Isla Grande de Chiloé and Concepción as the type localities, respectively. At the same time, Nicolet (1849) mentioned a third form, Latrodectus formidabilis Walckenaer, 1837, from Chile; this taxon was later considered as a synonym of $L$. mactans by Gerschman \& Schiapelli (1943) and of L. curacaviensis by Levi (1959). However, Platnick (2009) points out that L. mactans is not present in Chile and lists three Latrodectus species for Chile: 1) Latrodectus geometricus C. L. Koch, 1841, with a worldwide distribution; 2) Latrodectus curacaviensis (Müller, 1776) found in the Antillas and South America, with the exception of Argentina; and 3) L. variegatus Nicolet, 1849 with a restricted distribution in Chile and adjacent zones of Argentinean and Chilean Patagonia (Nicolet 1849; Levi 1959, 1967a, 1967b; Abalos 1980). It should be noted that no revisionary work has included more than one Chilean specimen of Latrodectus. Levi (1959) included one specimen identified as $L$. curacaviensis. The phylogenetic analysis of Garb et al. (2004) included a single Chilean specimen that was not identified at the species level and for which no information on its geographic origin was provided.

The present study is based on the analysis of morphological and molecular characters, and has the aim of clarifying the taxonomic identity and the distribution of the species of black widow present in continental Chile.

\section{MATERIALS AND METHODS}

\section{Material}

We studied a total of 229 females, 8 males and 98 immature specimens from three Chilean collections: Museo de Zoología de la Universidad de Concepción (MZUC-UCCC), Museo Nacional de Historia Natural (MNHN), and Laboratorio de Entomología y Ecología, Universidad de La Serena (LEULS), and the African National Museum Bloemfontein (NMB). Additional spiders were collected by the authors using a manual technique (Upton 1991; Sorensen et al. 2002), from 33 localities from Arica and Parinacota Region in northern Chile to the Magallanes and Antártica Chilena Region in southern Chile; these specimens were deposited in the MZUC-UCCC.

\section{MorPhOLOGICAL ANALYSIS}

Morphological descriptions follow those of Lotz (1994) and Abalos (1980). Measurements in the descriptions are in millimetres. The following two coefficients were calculated: cephalothoracic coefficient $(\mathrm{T})=$ cephalothorax length (without chelicerae) divided by cephalothorax wide; TT 
coefficient (TT) $=$ sum of the length of the patella and tibia on leg I divided by cephalothorax length (without chelicerae).

\section{Phylogenetic Analysis}

Design and sampling. Phylogenetic and genetic analyses were based on a fragment of the mitochondrial genome corresponding to the cytochrome oxidase subunit I (COI) gene. Analyses included sequences of nine Chilean specimens; eight of these were collected by us at the following two localities: 1) Casas Viejas, Comuna San Clemente, Región del Maule (35²7'40,2" S 71²9'16,8", W) $(n=7)$ and 2) Lomas Los Huasos, Andacollo, Región de Coquimbo (30¹3'49” S 715'9” W) $(n=1))$; the ninth Chilean haplotype, which lacks species determination and specific locality, was taken from GenBank (AY383074; Garb et al. 2004). The remaining sequences were downloaded from GenBank. Thus, our sampling includes 30 sequences of Latrodectus from 13 species (Table 1). As the monophyly of Latrodectus is well supported (Garb et al., 2004) the outgroup was constituted by a single representative of the false widow spiders theridiid genus Steatoda.

Sequence acquisition. DNA was extracted using a commercial (Promega) kit from one or two legs. The rest of the specimens were preserved as vouchers. A fragment of the COI gene was amplified with primers LCOI 1498 and HCO 2198 (Folmer et al. 1994). Amplifications were done in three stages: 1) initial denaturation at $94{ }^{\circ} \mathrm{C}$ for 90 seconds (s); 2) 35 cycles of denaturation at $94{ }^{\circ} \mathrm{C}$ for $30 \mathrm{~s}$, annealing at $55^{\circ} \mathrm{C}$ for $40 \mathrm{~s}$, and extension at $72{ }^{\circ} \mathrm{C}$ for $45 \mathrm{~s}$; and 3 ) final extension at $72{ }^{\circ} \mathrm{C}$ for $10 \mathrm{~min}$. Amplicons were sent to Macrogen Inc. Korea, for purification and sequencing. Obtained sequences were submitted to GenBank (accession numbers GU112098-105).

Sequence analysis. Sequence alignment was done with Clustal X (Thompson et al. 1997) using the default values for all alignment parameters. Observed percentage of sequence divergence was calculated with MEGA 4 (Tamura et al. 2007) ignoring those sites with missing data. Gene trees were inferred by Maximum Parsimony (Farris, 1983) using PAUP* (Swofford, 2000) with characters treated as unordered and with no weights. The search strategy consisted of 200 replicates of heuristic search with random addition of sequences and TBR branch swapping. Support for the nodes was assessed by a Jackknife (JK) analysis consisting of 1000 pseudo-replicates with 2 replicates of random addition of sequence, TBR branch swapping, and $33 \%$ of character deletion. Given that an haplotype was shared among newly sequenced specimens, redundant sequences were excluded from the analysis (see Fig. 1).

\section{RESULTS}

Of 646 characters, 186 were variable and 143 were parsimony-informative. The phylogenetic analysis recovered 442 equally parsimonious trees (length $=$ 458 steps; $\mathrm{CI}=0.555 ; \mathrm{RI}=0.627)$, the consensus of which (Fig. 1) is moderately resolved. As in Garb et al. (2004) the basal dichotomy of the Latrodectus clade was the geometricus group $(\mathrm{JK}=93)$, here represented by L. geometricus and L. rhodesiensis, and the mactans group ( $\mathrm{JK}=91)$, which contained the rest of the Latrodectus species included in our study. There was a well supported clade $(\mathrm{JK}=91)$ that contained Chilean haplotypes gathered by us, haplotypes gathered by Garb et al. (2004) from an unidentified Chilean specimen, other specimens identified as L. variegatus from the Argentinean provinces of Río Negro and Santa Cruz, and a haplotype recovered from a specimen identified as of L. mirabilis from Buenos Aires province. Sister to this clade is a second haplotype of L. mirabilis also from Buenos Aires Province, Argentina, which on average diverges by $0.8 \%$ from the clade containing the Chilean haplotypes; the resulting clade is also well supported $(\mathrm{JK}=92)$.

Morphological (see below) and phylogenetic analyses shown that all Chilean specimens analyzed belong to a single species. Comparisons with the descriptions and museum series of other taxa, allow us to conclude that the correct name to apply to the studied populations is Latrodectus thoracicus Nicolet, 1849, whose redescription follows.

Latrodectus thoracicus Nicolet, 1849

(Figs. 2-4)

Latrodectus thoracicus. Nicolet, 1849: 462.

Latrodectus formidabilis. Nicolet, 1849: 460, lam. 4, f. 10.

Latrodectus mactans. Gerschman \& Schiapelli, 1943: 16.

Latrodectus curacaviensis. Levi, 1959: 39 
TABLE I. List of specimens from where haplotypes of the COI gene used in the phylogenetic analysis were gathered. For those sequences generated here numbers of corresponding voucher specimens are provided (for locality data see Material Examined). Sequence marked with an asterisk was from an unidentified Chilean specimen and here referred to L. thoracicus.

TABLA I. Lista de especímenes a partir de los cuales se generaron los haplotipos del gen COI usados en el análisis filogenético. Para aquellas secuencias generadas en este estudio también se indica los correspondientes números de los especimenes vouchers (por datos de localidades ver Material Examined). El asterisco indica una secuencia generada por Garb et al. (2004) a partir de un espécimen chileno no identificado y que aquí es referido a L. thoracicus.

\begin{tabular}{|c|c|c|c|c|}
\hline & species & specimen voucher & accession number & source \\
\hline \multicolumn{5}{|c|}{ Ingroup } \\
\hline 1 & L. antheratus & & AY383048 & Garb et al. 2004 \\
\hline 2 & L. antheratus & & AY383047 & Garb et al. 2004 \\
\hline 3 & L. corallinus & & AY383062 & Garb et al. 2004 \\
\hline 4 & L. corallinus & & AY383061 & Garb et al. 2004 \\
\hline 5 & L. diaguita & & AY383063 & Garb et al. 2004 \\
\hline 6 & L. diaguita & & AY383064 & Garb et al. 2004 \\
\hline 7 & L. geometricus & & AY383066 & Garb et al. 2004 \\
\hline 8 & L. hasselti & & EF121035 & Vink et al. 2008 \\
\hline 9 & L. hesperus & & AY383071 & Garb et al. 2004 \\
\hline 10 & L. katipo & & EF121016 & Vink et al. 2008 \\
\hline 11 & L. mactans & & AY383072 & Garb et al. 2004 \\
\hline 12 & L. menavodi & & AY383075 & Garb et al. 2004 \\
\hline 13 & L. mirabilis & & AY383076 & Garb et al. 2004 \\
\hline 14 & L. mirabilis & & AY383077 & Garb et al. 2004 \\
\hline 15 & L. pallidus & & AY383055 & Garb et al. 2004 \\
\hline 16 & L. rhodesiensis & & AY383079 & Garb et al. 2004 \\
\hline 17 & L. thoracicus & & AY383074* & Garb et al. 2004 \\
\hline 18 & L. thoracicus & LT0204Cv01 & GU112098 & this study \\
\hline 19 & L. thoracicus & LT0105Cv01 & GU112099 & this study \\
\hline 20 & L. thoracicus & LT0105Cv02 & GU112100 & this study \\
\hline 21 & L. thoracicus & LT0105Cv03 & GU112101 & this study \\
\hline 22 & L. thoracicus & LT0105Cv05 & GU112102 & this study \\
\hline 23 & L. thoracicus & LT0108Cv01 & GU112103 & this study \\
\hline 24 & L. thoracicus & LT0108Cv02 & GU112104 & this study \\
\hline 25 & L. thoracicus & LT0903An01 & GU112105 & this study \\
\hline 26 & L. tredecimguttatus & & AY383080 & Garb et al. 2004 \\
\hline 27 & L. variegatus & & AY383084 & Garb et al. 2004 \\
\hline 28 & L. variegatus & & AY383083 & Garb et al. 2004 \\
\hline 29 & L. variolus & & AY383082 & Garb et al. 2004 \\
\hline \multicolumn{5}{|c|}{ Outgroup } \\
\hline 30 & Steatoda grossa & & AY383086 & Garb et al. 2004 \\
\hline
\end{tabular}




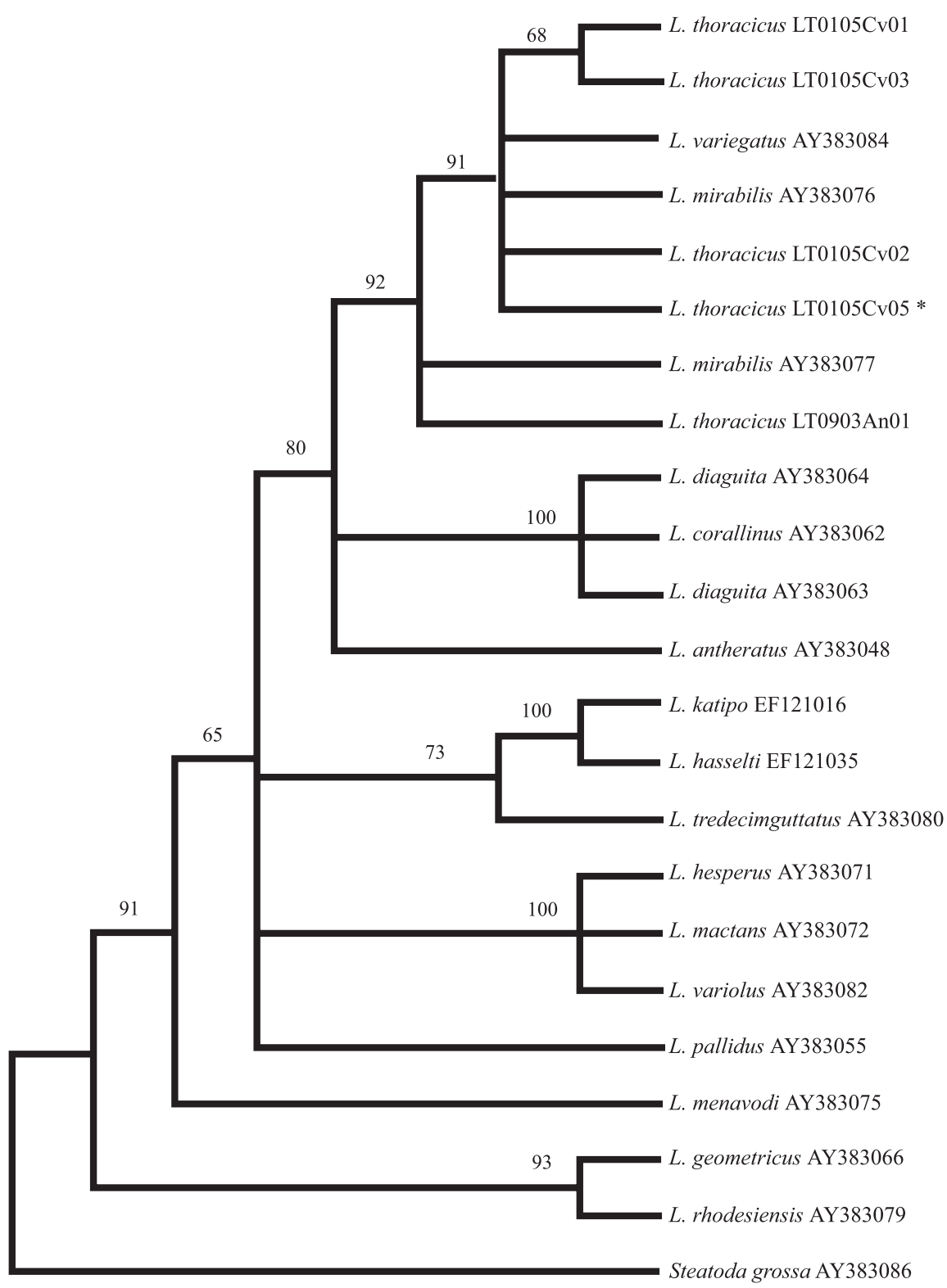

FIGURE 1: Strict consensus tree of 442 equally parsimonious trees (length $=458$ steps; $\mathrm{CI}=0.555 ; \mathrm{RI}=0.627$ ) resulting from the analysis of haplotypes of the COI gene of Latrodectus. Specimens of L. thoracicus LT0204Cv01, LT0108Cv01, and LT0108Cv01 share the same haplotype with specimen LT0105Cv05, which is marked with an asterisk. This haplotype is also shared by an unidentified Chilean specimen (AY383074) sequenced by Garb et al. (2004).

FIgURA 1: Consenso estricto de 442 árboles más cortos (longitud $=458$ pasos; $\mathrm{IC}=0.555 ; \mathrm{IR}=0.627$ ) resultados del análisis de haplotipos del gen COI de Latrodectus. Los especímenes de L. thoracicus LT0204Cv01, LT0108Cv01 y LT0108Cv01 comparten el haplotipo con el espécimen LT0105Cv05, el cual se identifica con un asterisco. Este haplotipo es también compartido por un espécimen chileno sin identificar (AY383074) secuenciado por Garb et al. (2004). 
HoLOTYPE

A female from Provincia de Concepcion, Chile. The type is lost.

\section{EMENDED DiAgnoses}

Opening of the epigynum oval to suboval, with anterior and posterior lips similar in length, and anterior margin often with a small lobulated median pointed process (Fig. 3a). Connecting ducts of the spermatheca with three loops in dorsal view; the second and third ones located at the side of the spermatheca and rotated over themselves in a single plane; the last loop outline almost an entire circle (Fig. 3c-3d). Embolus of the male palpus with three coils (Fig. 4a); the conductor placed in an angle larger than $90^{\circ}$, stout and strong in the distal third (Fig. 4c); radix lanceolate (Fig. 4d).
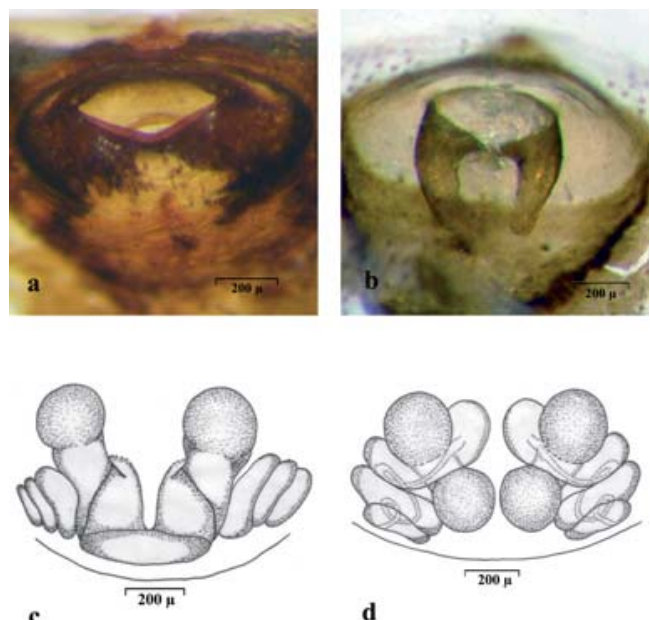

d

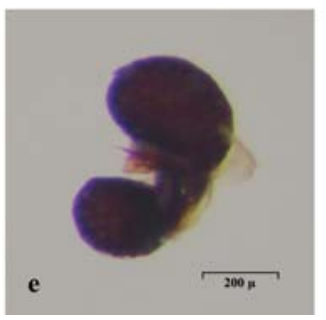

FiguRe 3: Latrodectus thoracicus: a) ventral view of the epiginium, b) dorsal view of the epiginium, c) ventral view of the internal genitalia, d) dorsal view of the internal genitalia, and e) lateral view of the left spermateca.

FIGURA 3: Latrodectus thoracicus: a) vista ventral del epiginio; b) vista dorsal del epiginio, c) vista ventral de la genitalia interna, d) vista dorsal de la genitalia interna, y e) vista ventral de espermateca izquierda.

\section{DESCRIPTION:}

Female: Cephalothorax, legs, and abdomen are shiny black (Fig. 2b). Abdomen with dorsal red or orange markings that are diverse in shape and arrangement (Fig. 2c-2d); ventrally with a trapezoid mark with a median cut between the spinnerets and epigastral furrow; the shape of this mark is slightly variable, but is generally the classic hourglass shape(Fig. 2e). Pair of circular spots present on each side of the lateral anterior and lateral posterior spinnerets (Fig. $2 \mathrm{f})$. The pattern of these spots varies according to age and geography (Fig. 2c-2d, 4f). The abdominal
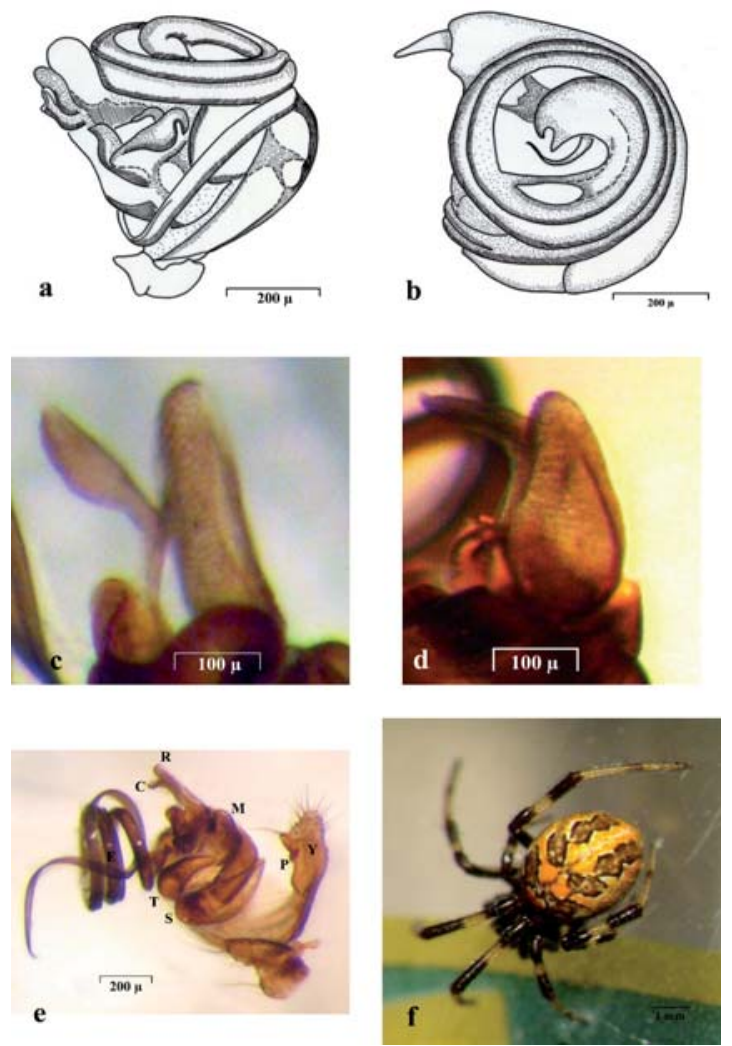

FIGURE 4: Latrodectus thoracicus: a) ventral view of the left palpus, b) ectal view of the left palpus, c) right palpus conductor, d) right palpus radix, e) ventral view of the right palpus, and f) immature specimen. $\mathrm{Y}=$ cymbium; $\mathrm{P}=$ paracymbial hook; $\mathrm{S}=$ subtegulum; $\mathrm{T}=$ tegulum; $\mathrm{M}=$ median apophysis; $\mathrm{E}=$ embolus; $\mathrm{R}=\operatorname{radix} ; \mathrm{C}=$ conductor.

Figura 4: Latrodectus thoracicus: a) vista ventral del palpo izquierdo, b) vista ectal del palpo izquierdo; c) conductor del palpo derecho, d) radix del palpo derecho, e) vista ventral del palpo derecho, y f) espécimen juvenil. Y, Cimbio; P, Gancho del cimbio; S, subtegulo; T, tegulo; $\mathrm{M}$, apófisis media; E, embolo; R, radix; $\mathrm{C}$, conductor. 

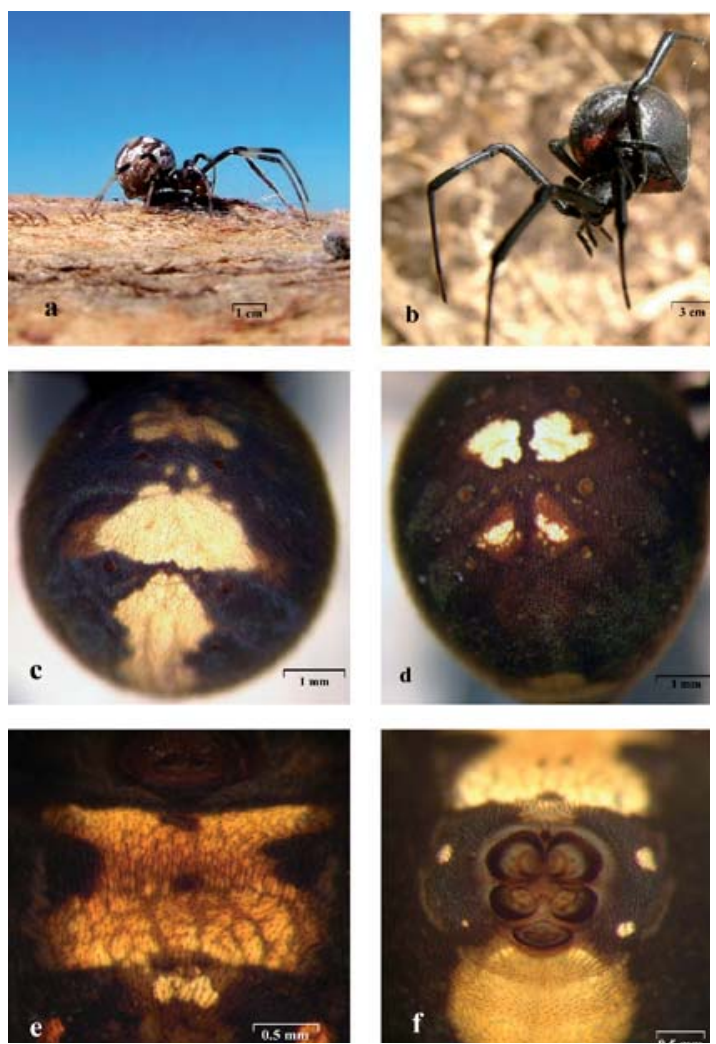

FIgURE 2: Latrodectus thoracicus: a) adult male, b-f) adult female, c-d) variations of dorsal pattern coloration, e) ventral pattern, and f) pattern around spinnerets.

FiguRA 2: Latrodectus thoracicus: a) macho adulto, b-f), hembra adulta, $c-d$ ) variaciones de patrones de manchas dorsales, e) patrón ventral, y f) manchas alrededor de las hilanderas.

dorsum with fine, curved setae of different lengths. Epigynum subgloboid, rugose and projecting; with an opening oval to suboval, wider than longer, with sclerotized lips and the anterior margin often with a small median pointed process as a lobule, and both lips similar in length (Fig. 3a-3b). Internal genitalia with two dumb-bell shaped spermathecae (Fig. 3e), V-shaped but with their bases separated; the connecting ducts with three loops, the second and third ones located at the side of the spermatheca and rotated over themselves in a single plane, while the last loop outline almost an entire circle (Fig. 3c-3d). Measurements of a sample of $\mathrm{n}=80$ are as follows: total length (excluding legs): 11.29 (10.8-13.1); cephalothorax length: 3.4 (1.3-5.8); width (at widest part): 3.0 (1.0-4.2); T coefficient: 1.12 (0.9-1.72); length tibia I: $3.8(0.5-5.7)$; length patella I: $1.6(0.6-$
5.33); TT coefficient: 1.59 (0.56-2.03).

Male: smaller than the female. Cephalothorax dark brown, wider than longer. Abdomen off-white, with four dark dorsal bands; two of them are irregular and located in the antero-medial part and project to the sides; the other two bands are elongated and directed to the posterior end. Legs longer than in the female; colour dark brown with creamy white stripes (Fig. 2a). Male palp and bulb typical for the genus; embolous with three coils (Fig. 4a, 4b, 4e); the conductor is placed in an angle larger than $90^{\circ}$, stout and strong in the distal third (Fig. 4c); radix lanceolate (Fig. 4d). Measurements as follows $(\mathrm{n}=8)$ : total length 2.27 (2.08-2.66); cephalothorax length: 0.94 (0.84-1.03); width: 0.96 (0.82-1.07); T coefficient: 0.98 (0.95-1.02); length tibia I: 181 (1.24-2.18); length patella I: 0.5 (0.39 - 0.62); TT coefficient: 2.43 (2.12-2.81).

Immatures: Around 55 days after emergence, individuals show basic characters of the genus (serrate setae on metatarsus IV, evident colulus with two setae, lateral eyes apart, and lack of teeth of the cheliceral margin). The coloration is characteristic, the cephalotorax and legs brown-orange, and dark brown between femur and patella. Dorsum of the abdomen with a series of rhomboidal dark brown spots (Fig. 4f). Venter with four circular and yellowish spots located around the spinnerets, and with a yellowish outline of the adult trapezoid spot located between the epigastral furrow and the spinnerets. Later the cephalothorax and the abdomen become black; abdomen with red spots or bands different in shape and variable arrangements.

Eggs: Spherical, yellowish, length between 0.82 and 0.94 (mean $=0.89$ ). Mean number of eggs on each egg sac is $536 \pm 48(\mathrm{n}=52)$.

Egg-sac $(\mathrm{n}=52)$ : spheroid or sometimes pearshaped, with a mean diameter of 9.76 (7.11-12.87); soft papery texture without surface ornamentations. When fresh, silk thread is present on the surface and is soft.

\section{Comparisons}

Females of $L$. thoracicus differ from those of the other Latrodectus species mentioned for Chile, $L$. variegatus, $L$. curacaviensis, and $L$. geometricus (Platnick 2009), by the arrangement of the spermathecae, the number of loops of the genitalia 
ducts, and the arrangement of the dorsal spots of the abdomen. Latrodectus geometricus has parallel spermathecae while those of $L$. thoracicus are placed in a V-formation. Latrodectus variegatus and $L$. curacaviensis (Abalos 1980) have spermathecal ducts with two loops, and $L$. thoracicus has three loops. Latrodectus curacaviensis has also a black abdomen with an elongated central band, surrounded by three pairs of bands placed obliquely (fide McCrone \& Levi 1964; Abalos 1980). Latrodectus thoracicus, on the other hand, has a black abdomen but with spots or bands of different shapes and variable arranged.

Males of $L$. thoracicus differ from those of $L$. variegatus, L. geometricus, and L. curacaviensis by the number of loops of the embolus and the shape of the conductor. The embolus of $L$. variegatus has two loops, that of $L$. geometricus has four, while that of $L$. thoracicus has three loops. In L. curacaviensis the distal third of the conductor is more or less cylindrical and in L. thoracicus is dilated.

\section{Distribution}

This species is found throughout Chile. It ranges from Arica y Parinacota Region in the north $\left(20^{\circ} \mathrm{S}\right)$ to Barranca Negra in Magallanes Region in the southern extreme of the continent $\left(50^{\circ} \mathrm{S}\right)$ and adjacent areas of Argentinean Patagonia. It is abundant in the central and southern parts of Chile.

\section{MATERIAL EXAMINED}

Región de Arica y Parinacota (XV): 1 \& Sapo Huira, Camino a Azapa. 21-Nov-1965, Tolar col. (MNHN Cat 774); Región de Tarapacá (I): 1 q La Tirana. Jun-2001, J. Ardiles col. (MZUC-UCCC); Región de Antofagasta (II): 1 q San Pedro de Atacama. 08Feb-2009, M. A. Aguilera col. (MZUC-UCCC); 1 ㅇ Calama. 12-Sep-1986, Ibarra col. (MZUC-UCCC); Región de Atacama (III): 21 - $4 \hat{\delta}$ Parc. Las Bombas, Camarones sur, Vallenar. 11-Feb-2004, M. A. Aguilera col. (MZUC-UCCC). 1 Algarrobal. 16-Sep-1984, Loyola col. (MZUC-UCCC); Región de Coquimbo (IV): Prov. del Choapa: 2 Los Molles. Oct-2003, Agusto y Espinoza col. (MZUCUCCC); Prov. del Elqui: 2 9 Andacollo. Sep-2003, P. Agusto col. (MZUC-UCCC); 1 \& Cerro la Coipa, Andacollo. 17-Aug-2003, P. Agusto col. (MZUCUCCC); 4 q Lomas Los Huasos, Andacollo. Sep2003, P. Agusto col. (MZUC-UCCC); 1 + Lomas Los Huasos, Andacollo. Sep-2003, P. Agusto col. LT0903An01 (MZUC-UCCC); 1 \& Cerro El
Curque, Andacollo. 23-Jul-2003, P. Agusto col.

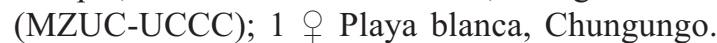
27-Feb-2005, J. Pizarro col. (MZUC-UCCC); 1 ㅇ Quebrada porotito, $35 \mathrm{~km} \mathrm{~N} \mathrm{La} \mathrm{Serena.} \mathrm{05-Jun-}$ 2004, D. Iriart col. (MZUC-UCCC); 1 q Quebrada porotito, $35 \mathrm{~km} \mathrm{~N} \mathrm{La} \mathrm{Serena.} \mathrm{16-Apr-2004,} \mathrm{J.}$ Pizarro col. (MZUC-UCCC); 1 Q Quebrada porotito, $35 \mathrm{~km} \mathrm{~N} \mathrm{La} \mathrm{Serena.} \mathrm{Jun-2004,} \mathrm{P.} \mathrm{Agusto}$ col. (MZUC-UCCC); 2 I Juan Soldado, N de La Serena. 05-Jun-2004. L. Espinoza col. (MZUCUCCC); 3 o Juan Soldado, N de La Serena. 05Jun-2004. J. Pizarro col. (MZUC-UCCC); 2 ㅇ Punta de Teatinos N La Serena. Sep-2003. L. Espinoza col. (MZUC-UCCC); 1 \& Totoralillo 15 km S Coquimbo. 01-May-2004. L. Espinoza col. (MZUC-UCCC); 1 † Vicuña. 05-Nov-2006. E. Cisterna col.; 42 \& Vicuña. 27-Dec-2007. E. Cisterna col. (MZUC-UCCC). Región del Maule (VII): Prov. Talca: 34 P Parc. 62, Casas Viejas, Com. San Clemente. 3-Feb-2004, M. A. Aguilera col. (MZUC-UCCC); 1 \& Parc. 62, Casas Viejas, Com. San Clemente. 3-Feb-2004, M. A. Aguilera col. LT0204Cv01 (MZUC-UCCC); 38 ○ -2 đ Parc. 62, Casas Viejas, Com. San Clemente. 5-Jan-2005, M. A. Aguilera col. (MZUC-UCCC); 5 Parc 62, Casas Viejas, Com. San Clemente. 5-Jan-2005, M. A. Aguilera col. LT0105Cv01, LT0105Cv02, LT0105Cv03, LT0105Cv04, LT0105Cv05 (MZUCUCCC); 14 - 2 § Parc. 62, Casas Viejas, Com. San Clemente. 20-Jan-2008, M. A. Aguilera col. 2 P Parc. 62, Casas Viejas, Com. San Clemente. 20-Jan-2008, M. A. Aguilera col. LT0108Cv01, LT0108Cv02 (MZUC-UCCC). Prov. Linares: 3 ㅇ Aeródromo, Linares. 15-Mar-2009. C. Pérez col. (MZUC-UCCC). Región del Bío - Bío (VIII): Prov. de Nuble: 1 + San Fabián de Alico. 28-Mar-2009. M. A. Aguilera col. (MZUC-UCCC). Prov. del Bío - Bío: 6 q Los Angeles. 18-Jan-1968, F. Haemmerli col. (MZUC-UCCC); 1 \& Los Angeles. 27-Feb2004. Y. Vera col. (MZUC-UCCC); 1 † Charrúa $10 \mathrm{~km}$ de Monteáguila. 13-Feb-2009. P. Oyarzún col. (MZUC-UCCC); 19 Quilaco 7 km E Quilaco. 11-Mar-2006. P. Arias col. (MZUC-UCCC); 1 Charrúa, 10 km de Monteáguila. 13-Feb-2009, Oyarzún col. (MZUC-UCCC); 1 † VII Región. Feb-2008. E. Hernández col. (MZUC-UCCC). Región de La Araucanía (IX): Prov. Malleco: 3 o km 8 entre Angol y Renaico. 23-Dec-1967, T. Cekalovic col. (MZUC-UCCC); 1 9 MallecoVictoria. Feb-1984, Anónimo (MNHN Cat 784). Prov. Cautín: 4 q Temuco. Dec-1983, Anónimo 
(MNHN Cat 869); 1 T Temuco, $40 \mathrm{~km} \mathrm{E} \mathrm{por}$ Huichahue. Prov. Cautín. Feb-1984, M. Vallejos col. (MNHN Cat 893); 11 Quino, Temuco. Feb2007, F. Romero col. (MZUC-UCCC); 1 \& Los riscos a $5 \mathrm{~km}$ de Pucón. 14-dic-1984, G. Weigert col. (MZUC-UCCC); 1 Q Río Huachitivo. 12-Feb81. T. Cekalovic col. (MZUC-UCCC). Región de Los Lagos (X): Prov. Llanquihue 4 O Calafquén. 20-Feb-2002, A. Larrain col. (MZUC-UCCC); Región de Magallanes y La Antártica Chilena (XII): Prov. Magallanes: 1 o Molco. 22-Feb-1983, T. Cekalovic col. (MZUC-UCCC); 1 \&arranca negra. 25-Jan-1955, T. Cekalovic col. (MZUCUCCC); 2 \& Barranca negra. 25-Dec-55, T. Cekalovic col. (MZUC-UCCC); 19 Cerro Guido. 20-Jan-66. T. Cekalovic col. (MZUC-UCCC).

\section{Natural History}

In the Central Valley of Chile L. thoracicus can be found in sunny areas with or without low herbaceous ground cover. Specimens shelter in holes in the ground, under pieces of wood and rocks or at the base of small bushes. It possible to find specimens associated with agricultural plantations such as those of oat, corn, alfalfa, and vineyards, where they are located close to the ground, under bales, among leaves and trunks of vineyards, blackberries or other bushes.

The webs of $L$. thoracicus are irregular and are placed on the ground or on the vegetation. It is possible to distinguish some specific areas in the web's structure: refuge zone, where the spider stays most of the time and places the egg-sacs; waste zone, where the spider leaves the food rests; capture zones, which correspond to all web places with the exception of those just mentioned. Another zone can be seen in the web where undigested preys are kept, wrapped with silk. Webs placed on the ground are more or less square and can be from few centimetres to up 0.5 meters wide. However, webs built on vegetation can extended longer than 2 meters from bottom to top and intermingle with the vegetation.

The most common prey of $L$. thoracicus are locusts, crickets, tenebrionids, scarabaeids, isopods, grasshoppers, and also other spiders. Occasionally L. thoracicus feeds on wasps.

Specimens can be found throughout most of the year, but the population fluctuates during the year. In the 2008 austral summer, two males were collected from a female's web during a search of leaves and trunks in a vineyard at San Clemente, Región del Maule. One of the males was in the web while the other was mating with the female. The timing of egg laying varies according to latitude; at $28^{\circ} \mathrm{S}$ it occurs in the first weeks of December, and at $35^{\circ} \mathrm{S}$ in the second week of January. Each female produce five egg-sacs.

\section{DISCUSSION}

Latrodectus thoracicus was described by Nicolet (1849) on the basis of one specimen collected near Concepción, central Chile. It was considered as a junior synonym of $L$. mactans by Gertchman \& Schiapelli (1943) and later of Latrodectus curacaviensis by Levi (1959). However, in these last two papers neither type nor topotypical material was examined. The characters mentioned by Nicolet (1849) in his description of L. thoracicus match those of immature specimens reared in this study. Therefore we suggest that Nicolet's description was based on an immature specimen and that the specimens here studied belong to L. thoracicus. Currently, after Gerschman \& Schiapelli (1943) L. thoracicus is considered as a junior synonym of $L$. mactans; and as such is listed (spelled as L. thoracius) in Platnick's (2009) catalogue, even when he does not include Chile in the distribution of L. mactans. Our assessment of patterns of morphological variation and the results of the phylogenetic analysis clearly indicate that $L$. thoracicus differs from both L. mactans and L. curacaviensis. Similarly, $L$. thoracicus morphologically differs from $L$. variegatus, another Chilean species described from Chiloe Island. Therefore, we consider L. thoracicus is a valid species.

Nicolet (1849) also mentioned L. formidabilis from Chile, but based on the information provided in his short description, we believe this record may represent $L$. thoracicus.

There is low genetic diversity of COI in populations of L. thoracicus; haplotypes recovered from Chilean populations diverge on average by only $0.5 \%$; this value is in line with those found by Vink et al. (2008) for species from New Zealand. The sample of $L$. thoracicus from San Clemente shows minimal haplotypic diversity. Four of seven specimens from this locality share the same haplotype; pairwise comparisons give an average value for this sample of $0.2 \%$. Remarkably, the 
most abundant haplotype found in San Clemente was also recovered from Argentinean specimens identified by Garb et al. (2004) as belonging to $L$. miriabilis and L. variegatus from Buenos Aires, Río Negro, and Santa Cruz provinces. This unexpected similarity may be due to the short sequence lengths (430 base pairs) obtained by Garb et al. (2004) from the Argentinean specimens and/or because species have retained an ancestral genetic variant (Pamilo $\&$ Nei 1988). However, this finding questions the distinction of these nominal forms or at least the correct determination of the specimens from where these haplotypes were gathered. It is possible that $L$. miriabilis is a junior synonym of $L$. thoracicus. We did not propose any formal change to the taxonomic status of L. miriabilis at this stage, because we have not had the opportunity to examine the specimens sequences by Garb et al. (2004) to check their correct identity. Latrodectus thoracicus is morphologically distinguishable from $L$. variegatus as described by Nicolet (1859). Therefore, we suggest that the specimens identified by Garb et al. (2004) as $L$. variegatus from Argentina belong in fact to $L$. thoracicus.

Two species of Latrodectus inhabit continental Chile. One species, L. variegatus, seems to be restricted to Chiloe Island. The second species $L$. thoracicus, is widely distributed in the country. We suggest that future studies should include the analysis of type material as well as of newly collected specimens from type localities as the only way of assigning the correct taxonomic names to mitochondrial haplotypes and morphotypes. Whatever the results of these studies might be, it is safe to assume that the current taxonomic scenario does not correctly reflect the alpha diversity of the genus Latrodectus and/or that species' geographic ranges are poorly delimited. Given the medical relevance of this genus, it would be valuable to conduct further field work and collection based taxonomic work in order to gain a correct appreciation of Latrodectus diversity and geographical distribution.

\section{ACKNOWLEDGMENTS}

To L. Lotz by sending specimens from Africa. To family Yáñez-Rodríguez and U. Monsalve for permits sampling at its site. To C. Oyarzún, P. Agusto, L. Espinoza, P. Arias, C. Pérez, E. Cisterna, and A. Larrain for sending specimens. To R. Chávez for the food to breed spiders. To C. Cañon for her help during laboratory work. To J. Ardiles and S. Gallardo for their continued support. To J. Miller and C. Vink for valuable suggestions on an earlier version of this paper. Grants DIUC 207.113.0751.0 and Fondecyt 11070157 provided financial support.

\section{REFERENCES}

Abalos, J.W. 1980. Las arañas del género Latrodectus en la Argentina. Obra Centenaria del Museo de La Plata 6: 29-51.

Artaza O., Fuentes J. \& Schindler, R. 1982. Latrodectismo: evaluación clínico-terapéutica de 89 casos. Revista Médica de Chile 110:1101-1105.

Artaza O., Fuentes J., Gómez P. \& Morris R. 1984. Latrodectismo (II): evaluación clínico-terapéutica de 78 casos. Parasitología al Día 8:45-49.

Canals, M., Casanueva, M.E. \& Aguilera M.A. 2004. ¿Cuáles son las especies de arañas peligrosas en Chile? Revista Médica de Chile 132(6): 773-6.

FARRIS, J.S. 1983. The logical basis for phylogenetic analysis. In: Platnick, I., Funk, V.A. (Eds.), Advances in Cladistics. Procedings of the second meeting. Willi Henning SocietyColumbia University Press, New York Vol. 2: 1-36.

FaúnDEZ, E.I. 2009. Arañas (Arachnida: Araneae) peligrosas de la Región de Magallanes. Anales Instituto Patagonia 37(1):127-131.

Folmer, O., Black, M., Hoen, W., Lutz, R. \& Vrijenhoek, R., 1994. DNA primers for amplification of mitochondrial cytochrome c oxidase subunit I from diverse metazoan invertebrates. Molecular Marine Biology and Biotechnology 3(5):294299.

Garb, J. E., GonzÁlez, A. \& Gillespie, R.G. 2004. The black widow spider genus Latrodectus (Araneae: Theridiidae): phylogeny, biogeography and invasion history. Molecular Phylogenetics and Evolution 31(3):1127-1142.

Gerschman, B.S. \& Schiapelli R.D. 1943. Revisión del género Latrodectus Walckenaer 1805. In Sampayo, R., Latrodectus mactans y latrodectismo. Buenos Aires, 2(Syst.):1-23.

Grishin, E. 1999. Polypeptide neurotoxins from spider venoms. European Journal of Biochemistry 264(2):276-280.

Levi, H.W. 1959. The spider genus Latrodectus (Araneae, Theridiidae). Transactions of the American Microscopical Society 78:7-43.

Levi, H.W. 1967a. Cosmopolitan and pantropical species of theridiid spiders (Araneae: Theridiidae). Pacific Insects 9:175-186.

Levi, H.W. 1967b. The Theridiid spider fauna of Chile. Bulletin of the Museum of Comparative Zoology $136: 1-20$. 
Lotz, L.N. 1994. Revision of the genus Latrodectus (Araneae: Theridiidae) in Africa. Navorsinge van die Nasionale Museum Bloemfontein. $10(1): 1-60$

Nicolet, A.C. 1849. Arácnidos. In Gay, C. (ed.), Historia Física y Política de Chile. Zoología 3: 319-543.

OrI, M. \& IKEDA, H. 1998. Spider Venoms and Spider Toxins. Journal of Toxicology. Toxin reviews 17(3): 405-426.

Orlova E.V., Rahman A., Gowen B., Volynski K.E., Ashton A.C., Manser C, van Heel, M. \& UshKARYov, Y.A. 2000. Structure of $\alpha$-latrotoxin oligomers reveals that divalent cation-dependent tetramers form membrane pores. Nature Structural \& Molecular Biology (7): 48-53.

Pamilo, P. \& NeI, M. 1988. Relationships between gene trees and species trees. Molecular Biology and Evolution 5(5):568-583.

Parodi, J., Romero, F., Miledi, R. \& Martínez, A. 2008. Some effects of the venom of the Chilean spider Latrodectus mactans on endogenous ion-currents of Xenopus laevis oocytes. Biochemical and Biophysical Research Communications 375(4):571575.

Platnick, N.I. 2009. The World Spider Catalog. Version 10.0. American Museum of Natural History. URL:http://research.amnh.org/entomology/ spiders/catalog81-87/index.html. Accesed: August 15, 2009.

Romero, F., Altieri, E., Quiñehual, C. \& Cayuqueo, A. 2000. Actividad contráctil del músculo papilar cardiaco y conducto deferente de rata inducida por veneno de la araña Latrodectus mactans de Chile. Gayana 64(2):161-170.

Romero, F., Altieri, E., Urrutia, M. \& Jara, J. 2003. Venom of Latrodectus mactans from Chile (Araneae, Theridiidae): effect on smooth muscle.
Revista de Biología Tropical 51(2):305-312.

Romero, F., Salvatici, R., Schulz, C., Cabezas, M., Standen, D. \& Altieri, E. 1996. Efecto del veneno de Latrodectus mactans sobre la respuesta contráctil del músculo papilar de rata. Revista Chilena de Cardiología 15(3):112.

SCHENONE, H. \& CORREA, L. 1985. Algunos conocimientos prácticos sobre la biología de la araña Latrodectus mactans y el síndrome de latrodectismo en Chile. Boletín Chileno de Parasitología 40(1-2):18-23.

Sorensen, L., Coddington, J.A. \& Scharff, N. 2002. Inventorying and estimating subcanopy spiders diversity using semiquantitative sampling methods in an Afromontane forest. Environmental Entomology 31(2):319-330.

Swofford, D.L. 2000. PAUP*. Phylogenetic Analysis using Parsimony (* and other methods). Sinauer Associates, Sunderland, Massachusetts.

Tamura, K., Dudley, J., Nei, M. \& Kumar, S. 2007. MEGA 4: Molecular Evolutionary Genetics Analysis (MEGA) software version 4.0. Molecular Biology and Evolution 24(8):1596-1599.

Thompson, J.D., Gibson, T.J., Plewniak, F., Jeanmougin, F. \& Higgins, D.G., 1997. The CLUSTAL X windows interface: flexible strategies for multiple sequence alignment aided by quality analysis tools. Nucleic Acids Research 25(24): 4876-4882.

UPTON, M.S. 1991. Methods for collecting, preserving, and studying insects and allied forms. The Australian Entomological Society, Miscellaneous Publication $\mathrm{N}^{0} 3$. 4th edition, Brisbane, Australia. $86 \mathrm{pp}$.

Vink, C.J., Sirvid, Jagoba, Malumbres-Olarte, J., Griffiths, J.W., Paquin, P., \& Paterson, A.M. 2008. Species status and conservation issues of New Zealand's endemic Latrodectus spider species (Araneae: Theridiidae). Invertebrate Systematics 22(6):589604 . 